\title{
Stability of WISC-R scores in students with borderline intellectual functioning
}

BACKGROUND
Previous studies on the measurement of intelligence in
students with learning difficulties indicate low stability
of results observed over time. Therefore, careful analysis
of changes in intelligence quotient, as well as in results
within Verbal and Performance scale subtests, is necessary.

\section{PARTICIPANTS AND PROCEDURE}

The aim of the research was to analyze changes in WISC-R scores over time in students with borderline intellectual functioning. Test-retest stability of WISC-R was evaluated for Full, Verbal (VIQ), and Performance (PIQ) scales. The study involved 30 students, who were tested three times, when their mean age was $8,10.8$, and 13.6 years old.

\section{RESULTS}

The results showed that Full Scale IQ was fairly stable over time and remained below the average level, between -1.01 and -2.00 standard deviations. Significant changes were observed in the Verbal and Performance scale; VIQ decreased and PIQ increased over time. An initially insignificant statistical difference between the scales grew as time progressed. Furthermore, considerable subtest score fluctuation was observed; over time scores in the Vocabulary subtest significantly decreased whereas in Block Design and Picture Arrangement they increased.

\section{CONCLUSIONS}

The authors argue that delayed acquisition of verbal skills may result from chronic school failure and deficiency of educational support experienced by this group of students. Meanwhile, non-verbal skills, that are less dependent on educational influences and academic knowledge, improve with students' development through their engagement in everyday life activities.

\section{KEY WORDS}

borderline intellectual functioning; intelligence quotient; cognitive profile; learning difficulties

ORganizations - 1: Institute of Psychology, University of Gdansk, Gdansk, Poland · 2: McGill University, Montreal,

Quebec, Canada

Authors' CONtribution - A: Study design - B: Data collection · C: Statistical analysis · D: Data interpretation ·

E: Manuscript preparation · F: Literature search · G: Funds collection

CORRESPONDING AUthor - Anna Maria Jankowska, Ph.D., Institute of Psychology, University of Gdansk,

4 Bażyńskiego Str., 80-952 Gdansk, Poland, e-mail: a.jankowska@ug.edu.pl

TO CITE THIS ARTICLE - Jankowska, A.M., Bogdanowicz, M. \& Takagi, A. (2014). Stability of the WISC-R scores

in students with borderline intellectual functioning. Health Psychology Report, 2(1), 49-59.

DOI: $10.5114 /$ hpr.2014.42789 


\section{INTRODUCTION}

Borderline intellectual functioning (BIF) describes a level of intelligence situated below the average range, but is not mental impairment. In the DSM-V, borderline intelligence (V62.89) is determined to be a form of developmental disorder (axis II), which requires clinical help but does not constitute a mental impairment (code V) (APA, 2013). Borderline intellectual functioning is diagnosed, among other things,
Anna Maria Jankowska, Marta Bogdanowicz, Anna Takagi on the basis of global test results situated between -1.01 and -2.00 standard deviations. For example, on the Wechsler Intelligence Scale for Children it is the global intelligence quotient ranging from 70 to 84 . Currently, the fourth edition of the scale (WISC-IV) (2003), which is the third revision of the original scale called the Wechsler-Bellevue Intelligence Scale (1939), is widely used internationally. The first two revisions were made in 1974 (WISC-R) and then in 1991 (WISC-III). The fifth edition of the test (WISC-V) will be available in the second half of 2014. In Poland, the one most commonly used is the second edition of the WISC (1974) (WISC-R). The newer adaptations of the test are not available.

In order to fully investigate borderline intelligence, it is necessary to conduct a clinical diagnosis. The American Psychiatric Association (2013) recommends taking particular care when examining individuals for whom results are situated within the range of 71 to $75 \mathrm{IQ}$, and making sure that a differential diagnosis of a mild mental impairment or borderline intelligence includes the analysis of the level of adaptation and independence achieved by the individuals.

In accordance with the normal distribution, the percentage of the population which is characterized by this level of intellectual functioning reaches nearly $14 \%$. Thus, in an average primary school class of 25 pupils, there are between 3 and 4 students having borderline intelligence (Cooper \& Cooter, 2004). According to some researchers, however, the number of individuals having this level of intelligence may be significantly higher (Hassiotis et al., 2008). MacMillan, Gresham, Siperstein and Bocian (1996) have estimated that the number of school-age children having borderline intelligence in the USA is equal to the total number of students belonging to all the categories of special education.

Students having borderline intelligence constitute a risk group in terms of long-term learning difficulties, repeating a school year, being expelled from school, having conflicts with the law, and suffering from dependence or mental disorders (Ahrens, Evans \& Barnett, 1990; Hassiotis et al., 2008; Masi, Marcheschi \& Pfanner, 1998). In the course of their formal education, nearly from the beginning, they experience numerous academic, social and emotional difficulties, and, with the passage of time, they fall into the vicious circle of professional and personal failures if they do not receive appropriate help (Jankowska, Bogdanowicz, Shaw \& Łockiewicz, 2012). In the USA and Canada, these students are popularly termed 'grey area kids'. This term refers to the complicated educational situation of these students, namely, the lack of an appropriate place in the schooling system. These children do not qualify for special educational institutions because, although their level of cognitive functioning is lower than average, it is not identified as a mental impairment. Since they do not receive appropriate help, these students are not capable of meeting the requirements of regular education (MacMillan, Gresham, Bocian \& Lambros, 1998). Throughout the years of their education, their problems accumulate and result in a vicious cycle of failures, which have serious consequences for their further professional and personal development.

Students having borderline intelligence are particularly sensitive to deprivation and lack of appropriate mental stimulation in their family and school environments (Masi et al., 1998). Neglecting to exert corrective and compensational influences amongst students experiencing learning difficulties, which includes those having borderline intelligence, results not only in the accumulation of failures in their functioning in school but also delays in the development of their cognitive skills. According to the Polish researcher Halina Spionek (1970), amongst students experiencing long-term learning difficulties and those with borderline intelligence, the accumulation of gaps in knowledge, difficulties in mastering basic school abilities, as well as the lack of mental training, may, as a consequence, result in a gradual decrease in the global results achieved on measures of intelligence. This researcher observed that, in comparison with the junior years of primary school (I and II), in older years (V and VI) twice as many children achieved results on a test of intelligence at the level of 70-80. In these studies, 48 students who were experiencing learning difficulties received psychological and pedagogical assessments at the beginning of primary school and then again after five years. Over the five years, the global intelligence quotient achieved on a test of intelligence significantly decreased. While at the beginning of primary school an IQ below 90 was ascertained in the case of as few as 6 children, after five years this number increased to 33 . In 26 students, the IQ decreased from the average level (90-109) in the first measurement to below 90 in the second measurement. A majority of the children originated from neglected family environments.

The stability of results achieved on measures of intelligence is a problem previously raised in foreign scientific studies. In students who do not experience failures in learning, the stability of WISC-R 
results over time is high (Tuma \& Applebaum, 1980; Wechsler, 1974). However, in children experiencing educational difficulties, much more changeability is observed. Naglieri and Pfeiffer (1983) examined 27 boys and 26 girls (aged: 6-13.5) having borderline intelligence at two time points using the WISC-R (IQ on the full version of the WISC-R was 74.6). Changes in intelligence quotients over the threeyear period were statistically significant, although on the Verbal Scale a nonsignificant decrease was observed. Nichols, Inglis, Lawson \& MacKey (1988) conducted studies on 224 students of both sexes who experienced learning difficulties and observed a gradual decrease in results on the Verbal Scale. Skills measured on the Non-verbal Scale showed a tendency to increase and then to decrease again. The authors suggested that an increase in results on the Non-verbal Scale represented compensation for very weakly developed verbal skills. These results are also compatible with the studies of Anderson, Cronin and Kazmierski (1989), who examined the stability of WISC-R results in students experiencing learning difficulties. The first measurement was conducted when the individuals were an average of 8.3 years old and the second measurement occurred when they were 11.7 years old. Using Student's $t$-test for dependent groups, a statistically significant decrease was observed on the Verbal Scale. The studies of Schmidt, Kuryliw, Saklofske and Yackulic (1989) of 36 students (average age 8.1 years) experiencing learning difficulties also showed that, as they got older, not only did the intelligence quotient on the Verbal Scale decrease, but so did the Full Scale IQ of the WISC-R. Bauman (1991) also conducted an analysis of the stability of WISC-R results over two periods amongst 130 students experiencing learning difficulties. In these studies, a significant decrease in results on the Full and Verbal Scales was observed. A decrease was observed not only in students having borderline intelligence but also in those having an IQ higher than average. In turn, results on the Non-verbal Scale increased. The author emphasized the necessity of regular monitoring of results on the WISC-R due to their significant instability.

Smith (1978) researched the stability of results on particular subtests of the WISC-R in 161 students experiencing learning difficulties, twice at 7-month intervals. The results indicated highly stable profiles, apart from the results in the Vocabulary subtest, which significantly decreased. Results on the Non-verbal Scale gradually increased. These results were in contrast to those obtained by Vance, Blixt, Ellis and Debell (1981). These authors studied WISC-R results at two time points in 75 students experiencing learning difficulties or with cognitive impairment. Across the two-year period, the full scale IQ and non-verbal IQ scores remained at the same level (between 1.01 and 2 SDs below the mean). However, scores in the Block Design subtest significantly decreased while scores in Picture Arrangement significantly increased. On the Verbal Scale, the mean IQ of these students significantly decreased (from 76.62 to 74.76). Specifically, scores decreased in the Similarities, Vocabulary, and Digit Span subtests. The authors concluded that the relative constancy of intelligence on the Non-verbal Scale and decreasing performance on the Verbal Scale most likely resulted from the fact that the majority of the students attended special schools which placed emphasis on their non-verbal skills and developing practical abilities. In addition, it is likely that low results on the Verbal Scale were at least partly due to the fact that the students seldom read, which additionally decreased their verbal skills (Vance et al., 1981).

The above overview of the research indicates that the results achieved on the WISC-R by children experiencing learning difficulties may be less stable over time, which is of critical significance for the reliable diagnosis of the process (Anderson, Cronin \& Kazmierski, 1989). As pointed out by Bauman (1991), the profiles of older children with BIF are more stable than those of younger children. The profiles of children whose cognitive functioning is higher than average are also more stable.

The goal of the present study was to analyze changes in the WISC-R profile of students having borderline intelligence, occurring over two periods. We were interested in the stability or the dynamics of change on the Full Scale, Verbal Scale, and Non-verbal Scale and in the particular subtests of the scales.

\section{PARTICIPANTS AND PROCEDURE}

The studies were conducted in a psychologicalpedagogical centre in Poland. Detailed analysis involved the results of three measurements of the WISC-R 30 scale in students of both sexes (23 boys and 7 girls), whose global intelligence quotient was situated between -1.01 and -2.00 (standard deviations) and who also received a psychological assessment ascertaining a level of intellectual functioning lower than average. The measurements were conducted when the participants were, on average, 8 years old (at the first measurement), 10.8 years old (at the second measurement) and 13.6 years old (at the third measurement).

Verification of the hypotheses concerning the dynamics of the cognitive development of students having borderline intelligence was conducted using a repeated measures analysis of variance (ANOVA) and also the analysis of contrasts, which served to test the hypothesis of the existence of a linear trend of change in the level of intelligence in particular measurements.
Stability of WISC-R in borderline intelligence students 


\section{RESULTS}

DYNAMICS OF CHANGES IN INTELLIGENCE QUOTIENT ON THE FULL SCALE, NON-VERBAL SCALE AND VERBAL SCALE

Analysis of the stability of intelligence quotients on the Full Scale of the WISC-R found that they did not undergo significant changes over time and remained at the level between -1.01 and $-2.00(S D)$. The results
Anna Maria Jankowska, Marta Bogdanowicz, Anna Takagi on the Full Scale showed a non-significant increase in the second measurement (10.8 years) and, afterwards, a decrease in the third measurement at the age of 13.6 years. Changes in intelligence quotients on the Full Scale are described in Table 1.

A gradual decrease was observed, however, in the case of intelligence quotients on the Verbal Scale of the WISC-R. At each measurement, the results on the Verbal Scale were situated at a lower level. A statistically significant difference was observed between the second and third measurements $(p<0.001)$. The lowest quotient on the Verbal Scale was achieved by students at the age of 13.6 years (in the third measurement).

The results of the comparison between the measurements of intelligence on the Verbal Scale are presented in Table 2.

The analysis of changes in the intelligence quotients on the Non-verbal Scale of the WISC-R across three measurements showed that in the case of students having borderline intelligence, their scores increased as they got older. Statistically significant changes between the first and second measurements were observed. More specifically, the non-verbal intelligence quotient increased significantly $(p=0.04)$ to the average level at the second measurement (when participants were 10.8 years of age) but then decreased at the third measurement, although this difference was not significant ( $p=$ $=0.18$ ). Results of the changes in intelligence quotient on the Non-verbal Scale are described in Table 3.

In order to additionally enrich knowledge about the dynamics of changes in intelligence quotients on the WISC-R amongst students having borderline intelligence, analysis of the differences between the Verbal and Non-verbal scales at each time point was also conducted. The post-hoc Tukey test method was used and the results are presented in Table 4.

Table 1

Intelligence quotients on the Full Scale of the WISC-R in three measurements

\begin{tabular}{|c|c|c|c|c|c|c|c|c|c|c|c|}
\hline \multirow{2}{*}{ Measurement } & \multicolumn{2}{|c|}{$\begin{array}{c}\text { Descriptive } \\
\text { statistics }\end{array}$} & \multicolumn{4}{|c|}{ Correlations } & \multicolumn{3}{|c|}{$\begin{array}{c}\text { Difference } \\
\text { significance test }\end{array}$} & \multicolumn{2}{|c|}{ Analysis of contrasts } \\
\hline & $M$ & $S D$ & SEM & I & II & III & $\begin{array}{c}F \\
(2.56) \\
\end{array}$ & $p$ & $\eta^{2}$ & $\begin{array}{l}\text { First vs. } \\
\text { second }\end{array}$ & $\begin{array}{l}\text { Second vs. } \\
\text { third }\end{array}$ \\
\hline $\begin{array}{c}\text { First } \\
(8 \text { years old })\end{array}$ & 77.83 & 7.86 & 1.46 & 1 & & & & & & $\begin{array}{l}F(1.28)= \\
\quad=0.71\end{array}$ & $\begin{array}{l}F(1.28)= \\
\quad=1.1\end{array}$ \\
\hline $\begin{array}{c}\text { Second } \\
(10.8 \text { years old })\end{array}$ & 79.48 & 8.67 & 1.61 & 0.19 & 1 & & 0.573 & 0.567 & 0.020 & $p=0.41$ & $p=0.30$ \\
\hline $\begin{array}{c}\text { Third } \\
\text { (13.6 years old })\end{array}$ & 78.10 & 4.82 & 0.90 & 0.10 & 0.42 & 1 & & & & $\eta^{2}=0.03$ & $\eta^{2}=0.04$ \\
\hline
\end{tabular}

Table 2

Intelligence quotients on the Verbal Scale of the WISC-R in three measurements

\begin{tabular}{|c|c|c|c|c|c|c|c|c|c|c|c|}
\hline \multirow{2}{*}{ Measurement } & \multicolumn{2}{|c|}{$\begin{array}{c}\text { Descriptive } \\
\text { statistics }\end{array}$} & \multicolumn{4}{|c|}{ Correlations } & \multicolumn{3}{|c|}{$\begin{array}{c}\text { Difference } \\
\text { significance test }\end{array}$} & \multicolumn{2}{|c|}{ Analysis of contrasts } \\
\hline & $M$ & $S D$ & SEM & I & II & III & $\begin{array}{c}F \\
(2.56) \\
\end{array}$ & $p$ & $\eta^{2}$ & $\begin{array}{l}\text { First vs. } \\
\text { second }\end{array}$ & $\begin{array}{l}\text { Second vs. } \\
\text { third }\end{array}$ \\
\hline $\begin{array}{c}\text { First } \\
(8 \text { years old })\end{array}$ & 79.59 & 9.81 & 1.85 & 1 & & & & & & $\begin{array}{l}F(1.28)= \\
\quad=0.58\end{array}$ & $\begin{array}{l}F(1.28)= \\
\quad=10.3\end{array}$ \\
\hline $\begin{array}{c}\text { Second } \\
(10.8 \text { years old })\end{array}$ & 77.76 & 8.80 & 1.66 & 0.10 & 1 & & 6.809 & 0.002 & 0.096 & $p=0.45$ & $p<0.001^{* *}$ \\
\hline $\begin{array}{c}\text { Third } \\
\text { (13.6 years old) }\end{array}$ & 77.07 & 8.87 & 1.68 & -0.51 & 0.33 & 1 & & & & $\eta^{2}=0.01$ & $\eta^{2}=0.14$ \\
\hline
\end{tabular}


Table 3

Intelligence quotients on the Non-verbal Scale of the WISC-R in three measurements

\begin{tabular}{|c|c|c|c|c|c|c|c|c|c|c|c|c|}
\hline \multirow{2}{*}{ Measurement } & \multicolumn{2}{|c|}{$\begin{array}{l}\text { Descriptive } \\
\text { statistics }\end{array}$} & \multicolumn{4}{|c|}{ Correlations } & \multicolumn{3}{|c|}{$\begin{array}{c}\text { Difference } \\
\text { significance test }\end{array}$} & \multicolumn{2}{|c|}{ Analysis of contrasts } & \\
\hline & $M$ & $S D$ & SEM & I & II & III & $\begin{array}{c}F \\
(2.56) \\
\end{array}$ & $p$ & $\eta^{2}$ & $\begin{array}{l}\text { First vs. } \\
\text { second }\end{array}$ & $\begin{array}{l}\text { Second } \\
\text { vs. third }\end{array}$ & \\
\hline $\begin{array}{c}\text { First } \\
(8 \text { years old })\end{array}$ & 80.31 & 9.44 & 1.75 & 1 & & & & & & $\begin{array}{l}F(1.28)= \\
\quad=4.72\end{array}$ & $\begin{array}{l}F(1.28)= \\
\quad=1.9\end{array}$ & \\
\hline $\begin{array}{c}\text { Second } \\
(10.8 \text { years old })\end{array}$ & 85.38 & 12.04 & 2.24 & 0.34 & 1 & & 2.31 & 0.054 & 0.105 & $p=0.04^{*}$ & $p=0.18$ & $\begin{array}{l}\text { Stability } \\
\text { of WISC-R }\end{array}$ \\
\hline $\begin{array}{c}\text { Third } \\
(13.6 \text { years old })\end{array}$ & 83.24 & 9.34 & 1.73 & 0.36 & 0.58 & 1 & & & & $\eta^{2}=0.14$ & $\eta^{2}=0.06$ & $\begin{array}{l}\text { in borderline } \\
\text { intelligence } \\
\text { students }\end{array}$ \\
\hline
\end{tabular}

Table 4

Differences between intelligence quotients on the Verbal Scale and Non-verbal Scale at three time points

\begin{tabular}{|c|c|c|c|c|c|c|c|}
\hline \multirow[b]{2}{*}{ Measurement } & \multirow[b]{2}{*}{$\begin{array}{l}\text { WISC-R } \\
\text { scale }\end{array}$} & \multicolumn{2}{|l|}{$\mathrm{I}$} & \multicolumn{2}{|l|}{ II } & \multicolumn{2}{|l|}{ III } \\
\hline & & $\begin{array}{c}\text { Non-verbal } \\
80.31\end{array}$ & $\begin{array}{c}\text { Verbal } \\
79.59\end{array}$ & $\begin{array}{c}\text { Non-verbal } \\
85.38\end{array}$ & $\begin{array}{c}\text { Verbal } \\
77.76\end{array}$ & $\begin{array}{c}\text { Non-verbal } \\
83.24\end{array}$ & $\begin{array}{c}\text { Verbal } \\
77.07\end{array}$ \\
\hline First & Non-verbal & 1 & & & & & \\
\hline (8 years old) & Verbal & 0.998 & 1 & & & & \\
\hline Second & Non-verbal & & & 1 & & & \\
\hline (10.8 years old) & Verbal & & & $0.001^{* *}$ & 1 & & \\
\hline Third & Non-verbal & & & & & 1 & \\
\hline (13.6 years old) & Verbal & & & & & $0.007^{* *}$ & 1 \\
\hline
\end{tabular}

Table 5

Results calculated in the Vocabulary test on the Verbal Scale of the WISC-R in three measurements

\begin{tabular}{|c|c|c|c|c|c|c|c|c|c|c|c|}
\hline \multirow{2}{*}{ Measurement } & \multicolumn{2}{|c|}{$\begin{array}{l}\text { Descriptive } \\
\text { statistics }\end{array}$} & \multicolumn{4}{|c|}{ Correlations } & \multicolumn{3}{|c|}{$\begin{array}{l}\text { Difference signifi- } \\
\text { cance test }\end{array}$} & \multicolumn{2}{|c|}{ Analysis of contrasts } \\
\hline & M & $S D$ & SEM & I & II & III & $\begin{array}{c}F \\
(2.56) \\
\end{array}$ & $p$ & $\eta^{2}$ & $\begin{array}{l}\text { First vs. } \\
\text { second }\end{array}$ & $\begin{array}{l}\text { Second } \\
\text { vs. third }\end{array}$ \\
\hline $\begin{array}{c}\text { First } \\
(8 \text { years old })\end{array}$ & 7.93 & 2.02 & 0.37 & 1 & & & & & & $\begin{array}{l}F(1.28)= \\
=12.85\end{array}$ & $\begin{array}{l}F(1.28)= \\
\quad=3.35\end{array}$ \\
\hline $\begin{array}{c}\text { Second } \\
(10.8 \text { years old })\end{array}$ & 6.34 & 2.26 & 0.42 & 0.22 & 1 & & 14.037 & $<0.001$ & 0.334 & $p<0.001^{* *}$ & $p=0.08$ \\
\hline $\begin{array}{c}\text { Third } \\
(13.6 \text { years old })\end{array}$ & 5.52 & 2.23 & 0.41 & 0.37 & 0.24 & 1 & & & & $\eta^{2}=0.32$ & $\eta^{2}=0.11$ \\
\hline
\end{tabular}

As participants got older, the difference between Verbal and Non-Verbal IQ scores increased. In the first measurement, the difference between the quotients was not statistically significant $(p=0.998)$. Thus, at
8 years of age, verbal and non-verbal skills in students with borderline intelligence were developing harmoniously and were at a level lower than average. Slightly different results were obtained in the subsequent 
two measurements. At both time points, when participants were 10.8 years of age and then 13.6 years of age, the difference between Verbal IQ and Non-verbal IQ scores was statistically significant. The greatest divergence was observed at the second measurement (10.8 years old), in which case verbal skills remained at a level lower than the average one while non-verbal skills were average (Table 5).

Anna Maria Jankowska, Marta Bogdanowicz, Anna Takagi

\section{DYNAMICS OF CHANGES IN COGNITIVE SKILLS MEASURED WITH THE APPLICATION OF THE WISC-R VERBAL AND NON-VERBAL SCALE SUBTESTS}

We were also interested in changes in the development of specific cognitive skills. To do this, we analyzed the results of the 10 core WISC-R subtests at each time point. Supplemental subtests were not included. We found statistically significant changes in performance in certain subtests. On the Verbal Scale, as students got older, only the Vocabulary subtest score significantly decreased. Results of the Comprehension test slightly increased but this difference was not significant. In the Information, Similarities and Arithmetic subtests, the results remained unchanged and at a low level (Fig. 1).

In the Vocabulary subtest, the results gradually decreased across the three measurements. Contrast analysis showed a statistically significant difference $(p<0.001)$ between the first and second time point, while the difference between the second and third time points approached but did not reach signifi- cance $(p=0.08)$. At the first measurement at 8 years of age, performance was borderline average (7.93), while at the age of 13.6 (in the third measurement) performance decreased to a low level (5.52).

The only subtest on the Verbal Scale in which scores increased systematically was Reasoning; however, this increase was not statistically significant (Table 6).

Analysis of the dynamics of changes in non-verbal skills measured by the Non-verbal Scale of the WISC-R showed a tendency to increase. As the students got older, results in the majority of the subtests increased. However, statistically significant changes were found for only three non-verbal tests: Picture Completion, Picture Arrangement, and Block Design. Changes in non-verbal skills on the Non-verbal Scale are presented in Fig. 2.

In the Picture Completion subtest, scores increased from below average to the average level in the second measurement (at the age of 10.8 years). The difference between the results was not, however, statistically significant $(p=0.11)$. In the third measurement the results were lower than in the first and second measurements. Contrast analysis showed that the difference between the second and third measurements was statistically significant $(p=0.04)$ (Table 7).

Results of the Picture Arrangement subtest indicated that scores increased at age 10 (in the second measurement) but then decreased at age 13.6 years (in the third measurement). However, only the difference between the first and second measurements was statistically significant $(p=0.02)$ (Table 8). Im-

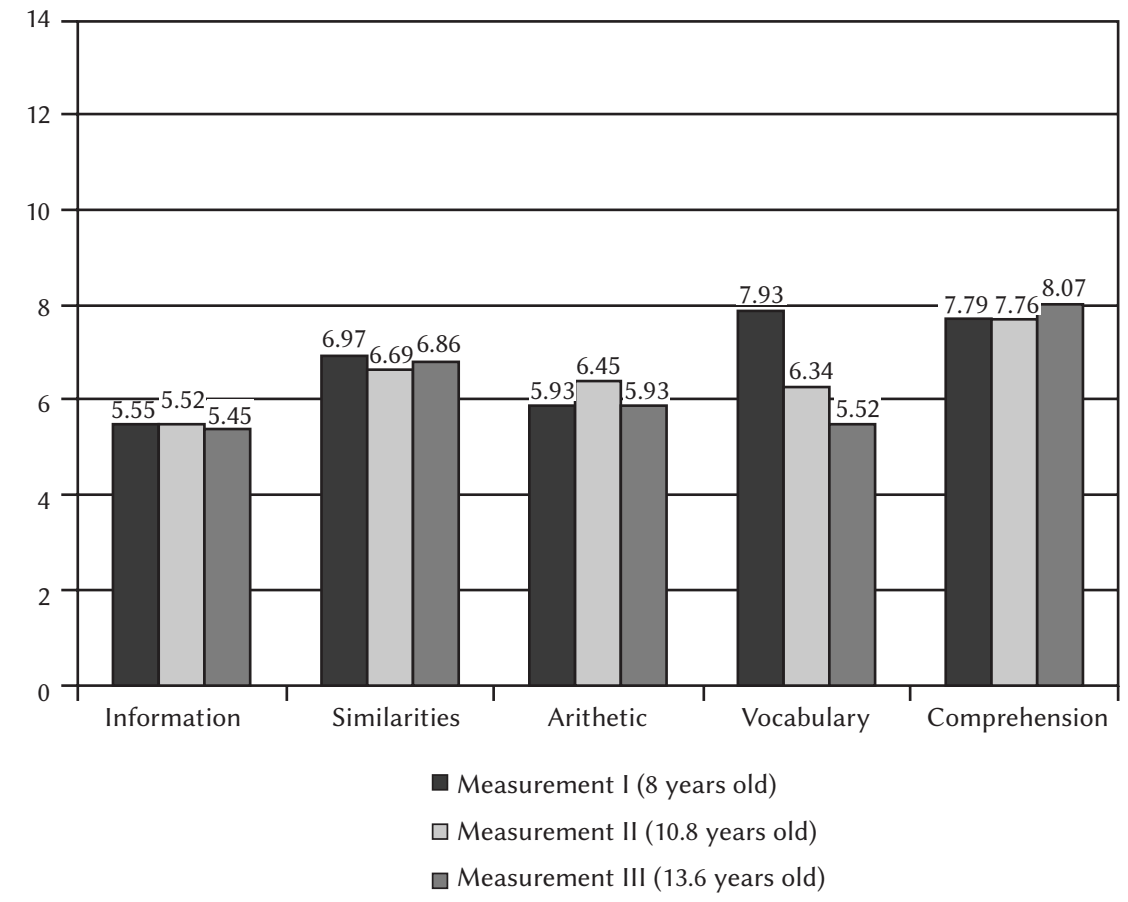

Figure 1. WISC-R Verbal Scale mean scaled scores 


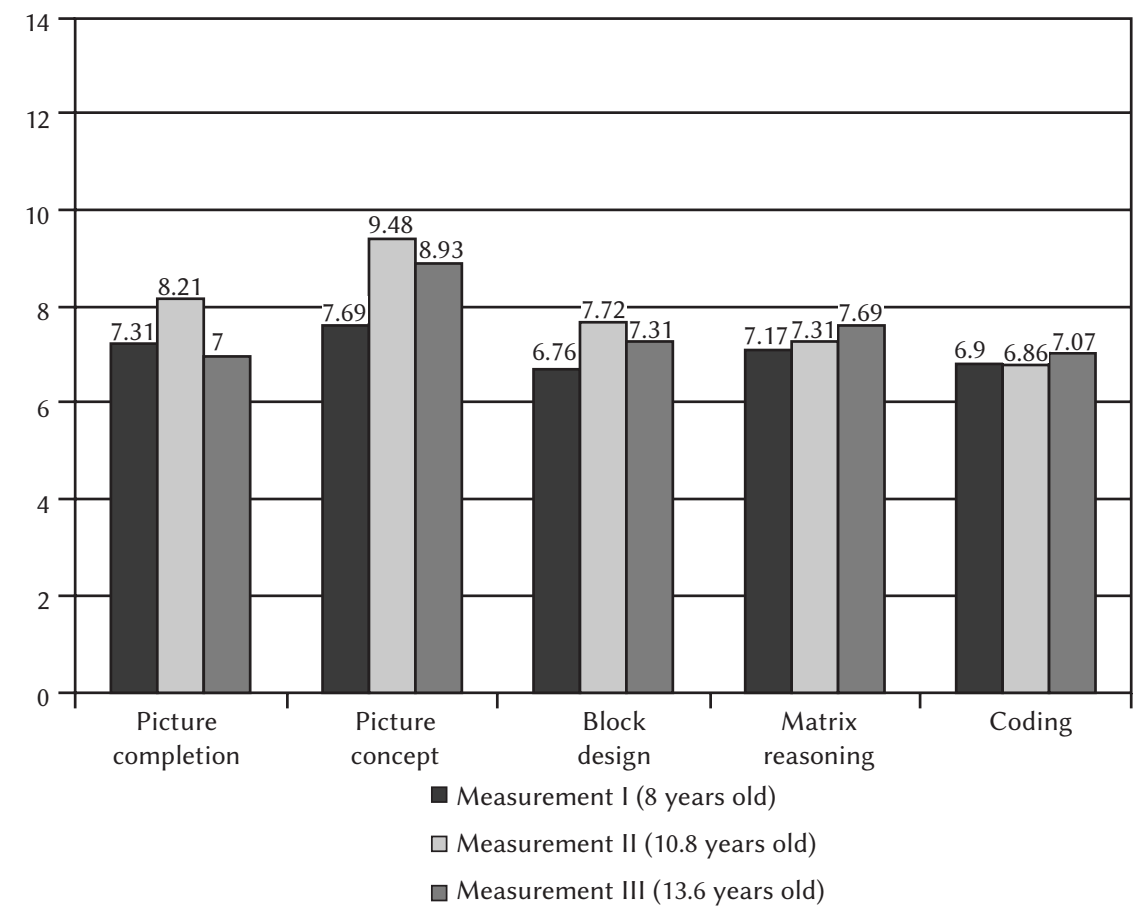

Stability of WISC-R in borderline intelligence students

Figure 2. WISC-R Performance Scale mean scaled scores

Table 6

Results calculated in the Comprehension test on the Verbal Scale of the WISC-R in three measurements

\begin{tabular}{|c|c|c|c|c|c|c|c|c|c|c|c|}
\hline \multirow{2}{*}{ Measurement } & \multicolumn{3}{|c|}{$\begin{array}{l}\text { Descriptive } \\
\text { statistics }\end{array}$} & \multicolumn{3}{|c|}{ Correlations } & \multicolumn{3}{|c|}{$\begin{array}{l}\text { Difference signifi- } \\
\text { cance test }\end{array}$} & \multicolumn{2}{|c|}{ Analysis of contrasts } \\
\hline & $M$ & $S D$ & SEM & I & II & III & $\begin{array}{c}F \\
(2.56)\end{array}$ & $p$ & $\eta^{2}$ & $\begin{array}{l}\text { First vs. } \\
\text { second }\end{array}$ & $\begin{array}{l}\text { Second vs. } \\
\text { third }\end{array}$ \\
\hline $\begin{array}{c}\text { First } \\
(8 \text { years old })\end{array}$ & 7.79 & 2.50 & 0.46 & 1 & & & & & & $\begin{array}{l}F(1.28)= \\
\quad=0\end{array}$ & $\begin{array}{l}F(1.28)= \\
\quad=0.32\end{array}$ \\
\hline $\begin{array}{c}\text { Second } \\
(10.8 \text { years old })\end{array}$ & 7.76 & 2.15 & 0.40 & -0.08 & 1 & & 0.139 & 0.850 & 0.005 & $p=0.96$ & $p=0.58$ \\
\hline $\begin{array}{c}\text { Third } \\
(13.6 \text { years old })\end{array}$ & 8.07 & 2.53 & 0.47 & 0.18 & 0.24 & 1 & & & & $\eta^{2}=0$ & $\eta^{2}=0.01$ \\
\hline
\end{tabular}

Table 7

Results calculated in the Picture Completion test on the Non-verbal Scale of the WISC-R in three measurements

\begin{tabular}{|c|c|c|c|c|c|c|c|c|c|c|c|}
\hline \multirow{2}{*}{ Measurement } & \multicolumn{2}{|c|}{$\begin{array}{l}\text { Descriptive } \\
\text { statistics }\end{array}$} & \multicolumn{4}{|c|}{ Correlations } & \multicolumn{3}{|c|}{$\begin{array}{c}\text { Difference significance } \\
\text { test }\end{array}$} & \multicolumn{2}{|c|}{ Analysis of contrasts } \\
\hline & M & $S D$ & SEM & I & II & III & $\begin{array}{c}F \\
(2.56) \\
\end{array}$ & $p$ & $\eta^{2}$ & $\begin{array}{l}\text { First vs. } \\
\text { second }\end{array}$ & $\begin{array}{l}\text { Second } \\
\text { vs. third }\end{array}$ \\
\hline $\begin{array}{c}\text { First } \\
(8 \text { years old })\end{array}$ & 7.31 & 2.16 & 0.40 & 1 & & & & & & $\begin{array}{l}F(1.28)= \\
\quad=2.71\end{array}$ & $\begin{array}{l}F(1.28)= \\
\quad=4.68\end{array}$ \\
\hline $\begin{array}{c}\text { Second } \\
(10.8 \text { years old })\end{array}$ & 8.21 & 2.51 & 0.47 & 0.22 & 1 & & 2.580 & $0.085 \mathrm{~A}$ & 0.084 & $p=0.11$ & $p=0.04^{*}$ \\
\hline $\begin{array}{c}\text { Third } \\
\text { (13.6 years old })\end{array}$ & 7.00 & 2.39 & 0.44 & 0.15 & 0.36 & 1 & & & & $\eta^{2}=0.09$ & $\eta^{2}=0.14$ \\
\hline
\end{tabular}


Table 8

Results of the Picture Arrangement subtest on the Non-verbal Scale of the WISC-R in three measurements

\begin{tabular}{|c|c|c|c|c|c|c|c|c|c|c|c|}
\hline \multirow{2}{*}{ Measurement } & \multicolumn{2}{|c|}{$\begin{array}{c}\text { Descriptive } \\
\text { statistics }\end{array}$} & \multicolumn{4}{|c|}{ Correlations } & \multicolumn{3}{|c|}{$\begin{array}{l}\text { Difference signifi- } \\
\text { cance test }\end{array}$} & \multicolumn{2}{|c|}{ Analysis of contrasts } \\
\hline & $M$ & $S D$ & SEM & I & II & III & $\begin{array}{c}F \\
(2.56) \\
\end{array}$ & $p$ & $\eta^{2}$ & $\begin{array}{l}\text { First vs. } \\
\text { second }\end{array}$ & $\begin{array}{c}\text { Second } \\
\text { vs. third }\end{array}$ \\
\hline I & 7.69 & 3.03 & 0.56 & 1 & & & & & & $\begin{array}{c}F(1.28)= \\
\quad=6.75\end{array}$ & $\begin{array}{c}F(1.28)= \\
\quad=1.34\end{array}$ \\
\hline II & 9.48 & 2.52 & 0.47 & 0.11 & 1 & & 3.062 & $0.035^{*}$ & 0.124 & $p=0.02^{*}$ & $p=0.26$ \\
\hline III & 8.93 & 2.49 & 0.46 & -0.08 & 0.28 & 1 & & & & $\eta^{2}=0.19$ & $\eta^{2}=0.05$ \\
\hline
\end{tabular}

Anna Maria Jankowska, Marta

Bogdanowicz, Anna Takagi

Table 9

Results of the Block Design subtest on the Non-verbal Scale of the WISC-R in three measurements

\begin{tabular}{|c|c|c|c|c|c|c|c|c|c|c|c|}
\hline \multirow{2}{*}{ Measurement } & \multicolumn{2}{|c|}{$\begin{array}{l}\text { Descriptive } \\
\text { statistics }\end{array}$} & \multicolumn{4}{|c|}{ Correlations } & \multicolumn{3}{|c|}{$\begin{array}{c}\text { Difference significance } \\
\text { test }\end{array}$} & \multicolumn{2}{|c|}{ Analysis of contrasts } \\
\hline & $M$ & $S D$ & SEM & I & II & III & $\begin{array}{c}F \\
(2.56) \\
\end{array}$ & $p$ & $\eta^{2}$ & $\begin{array}{l}\text { First vs. } \\
\text { second }\end{array}$ & $\begin{array}{c}\text { Second } \\
\text { vs. third }\end{array}$ \\
\hline $\begin{array}{c}\text { First } \\
(8 \text { years old })\end{array}$ & 6.76 & 2.17 & 0.40 & 1 & & & & & & $\begin{array}{l}F(1.28)= \\
\quad=5.08\end{array}$ & $\begin{array}{l}F(1.28)= \\
\quad=1.19\end{array}$ \\
\hline $\begin{array}{c}\text { Second } \\
\text { (10.8 years old) }\end{array}$ & 7.72 & 2.14 & 0.40 & 0.43 & 1 & & 2.937 & $0.061 \mathrm{~A}$ & 0.096 & $p=0.03^{*}$ & $p=0.29$ \\
\hline $\begin{array}{c}\text { Third } \\
(13.6 \text { years old })\end{array}$ & 7.31 & 2.07 & 0.38 & 0.51 & 0.44 & 1 & & & & $\eta^{2}=0.15$ & $\eta^{2}=0.04$ \\
\hline
\end{tabular}

Table 10

Dynamics of cognitive development in the factor analysis with the application of the Cattell-Horn model

\begin{tabular}{cccc}
\hline & First measurement & Second measurement & Third measurement \\
\hline Crystallized intelligence & 7.18 & 7.16 & 6.96 \\
Fluid intelligence & 6.9 & 7.53 & 7.34 \\
\hline
\end{tabular}

portantly, results of this subtest at age 8 years were below average, and, as the students got older, results increased to the average level.

In addition, performance in the Block Design subtest significantly increased from 8 years of age (first time point) to 10.8 years $(p=0.03)$. Performance then decreased at 13.6 years of age although the difference was not significant (Table 9).

\section{DISCUSSION}

According to the results of the present study, the global IQ of students having borderline intelligence did not undergo significant changes at subsequent measurements, and remained at a level below average. However, statistically significant changes were observed on the Verbal Scale and the Non-verbal Scale IQ scores of the WISC-R - as the students got older, the verbal intelligence quotient decreased while the non-verbal intelligence quotient significantly increased. The obtained results are partly compatible with the results of previous studies. A decrease in performance on the Verbal Scale in students experiencing learning difficulties was observed by Covin (1977), Haynes and Howard (1986) and Bauman (1991). Additionally, a significant increase and a nonsignificant decrease in performance on the Non-verbal Scale, also amongst students experiencing learning difficulties, was observed by Nichols and collaborators (1988). In turn, in studies devoted to the stability of results of the WISC-R in students having borderline intelligence, conducted by Naglieri and Pfeiffer (1983), changes were observed on the Verbal Scale but a decrease in IQ on this scale was not statistically significant.

A factor analysis using the Cattell-Horn model showed a gradual decrease in results in the factor of 
crystallized intelligence (dependent on the course of formal and informal education, or the level of the influences of the family environment, supporting the cognitive development of children), with a simultaneous increase in the results in fluid intelligence (dependent on the level of the development of the nervous system). The results are presented in Table 10.

A decrease in the results on the Verbal Scale was influenced by the Vocabulary subtest, which was the only subtest that significantly decreased over time, from average to below average. No other significant changes were observed in the remaining subtests, although performance in the Comprehension subtest slightly increased. These results are somewhat consistent with results from the study by Vance et al. (1981) that found that in students experiencing learning difficulties, performance significantly decreased in the Vocabulary subtest as well as in the Similarities and Digit Span subtests, which was not the case in the present study.

In accordance with the observations of Spionek (1970), students having borderline intelligence had decreasing ability to use verbal reasoning over time. The results indicated that the development of these students' linguistic abilities was delayed, as were their vocabulary and ability to verbalize their thoughts. The weak development of verbal skills in students having borderline intelligence may result from the lack of appropriate therapeutic assistance and also from the lack of mental training (avoiding intellectual work, a decrease in cognitive curiosity). Frequently, due to the lack of readiness to learn, a slow learning pace, and decreased ability to work with material of an abstract nature, these students master basic school abilities with a significant delay and experience failures as a result (Jankowska, Boganowicz \& Łockiewicz, 2013). The accumulation of educational difficulties may exert a negative influence on the process of acquiring knowledge and new skills and, ipso facto, the development of verbal competencies. Children from poorly functioning or culturally poor families may be particularly sensitive to delays in the development of verbal skills. The lack of appropriate support in the environment of education results in the accumulation of a backlog in knowledge, and the lack of mental training exerts an influence on the decreasing results in the verbal tests of the WISC-R.

One of the first and most frequent consequences of learning difficulties is decreasing motivation to learn (Shaw, 2008). Withdrawal from completing educational tasks (cognitive passivity) restricts the quantity of school activities in which knowledge, the store of vocabulary and abilities to formulate verbal utterances correct in terms of semantics and grammar are developed. The result of this phenomenon is a gradual decrease in performance in the Vocabulary Subtest. According to Ryan, Sattler and Lopes
(2000), the Vocabulary subtest on the Wechsler scale is the best predictor of crystallized intelligence, which is sensitive to the effects of formal education, the level of academic achievements, and also longterm learning difficulties. What is more, according to Wojnarska (2003), as students with borderline intelligence got older, the efficiency of oral memory decreased. Perhaps this also exerted an influence on the low results achieved on the Verbal Scale of the WISC-R in the present study.

An increase in performance in the Comprehension subtest ought to be interpreted in the context of changes in the remaining tests of the Non-verbal Scale. Although this test is included in the set of verbal subtests, it measures, first and foremost, the ability to use cause-and-effect thinking, planning and predicting, and also the store of knowledge about standards and norms of practical behavior. All these abilities develop to a greater degree under the influence of social experience, a child's own activity and solving problems in daily life than in the process of formal education. Students having borderline intelligence develop slightly more slowly than their peers; nevertheless, because in their case a particular type of thinking dominates, this development is faster and more effective nowhere else than in non-verbal spheres. According to the dynamics of changes in the results of non-verbal tests, the most important (in terms of statistics) changes were observed in the Picture Arrangement subtest, which increased from below average to average. An increase in the Picture Arrangement and Comprehension (insignificant) subtests most likely indicates the gradual development of knowledge and social skills, and the ability to understand generally accepted norms and standards of behavior. At the average level, their general ability of reasoning, cause-and-effect thinking, predicting the results of events and ability to plan were developed. Increasing performance in the Picture Arrangement subtest was also observed by Vance et al. (1981).

An increase in performance in non-verbal skills was observed as well, more specifically in the Block Design subtest, from a low level up to a level below average. These skills include visual-spatial functions, visual-motor analysis and visual synthesis. The development of these functions is connected with the activity of a child in the surrounding environment, and his or her experience in performing actions on items and manipulating them (Tyszkowa, 1990). One of the essential characteristic features of students having intelligence lower than average is their preference for acting on particular and tangible items (Shaw, 2008).

Different, but still statistically significant, changes were observed in performance in the Picture Completion subtest. After a nonsignificant increase to an average level at the age of 10 years (in the second
Stability of WISC-R in borderline intelligence students 
Anna Maria Jankowska, Marta Bogdanowicz, Anna Takagi measurement), the results then showed a significant decrease to a level below average (in the third measurement). This significant decrease in Picture Completion may be caused by the same factors observed in the case of the Vocabulary subtest - longterm learning difficulties and educational failures, and also deepening gaps in knowledge and deficits in school abilities. This subtest is sensitive to the level of knowledge possessed by a student and determined by the course of formal and informal education, and influences exerted by the family environment (Krasowicz-Kupis \& Wiejak, 2006). Ability to identify items, understand their functions and perceive the lack of their elements is decreased in a situation in which the direct experiences of a child are not as rich as they used to be, which is frequently a result of long-term failures in learning and the withdrawal of a student from school activities.

The dynamics of the development of cognitive skills of students having borderline intelligence indicate that as the students got older, the difference between their verbal and non-verbal skills increased. This increasing difference is connected to a decrease in the development of verbal skills and the simultaneous development of practical skills in the studied group. The development of non-verbal skills is a result of increasing practical experience of a child. Ability to think logically, predict the results of events, plan, observe relationships, and also cause-and-effect reasoning, are developed in the course of solving practical problems (Anderson, Cronin \& Kazminski, 1989). Delays in the speed of development of verbal skills were most likely connected with increasing learning difficulties in a school setting. Weakened verbal skills and decreased linguistic development exert a negative influence on the process of acquisition of basic school abilities, such as reading and writing. The lack of appropriate mastering of these abilities makes it impossible to develop more advanced school competencies, which, in turn, leads to the accumulation of difficulties in the acquisition, organization and retrieval of knowledge (Shaw, 2008), typical in this group of students. One consequence is the child's inability to assimilate knowledge and skills as quickly as their peers.

All these factors result in a phenomenon which may colloquially be called the "snowball effect". Namely, already initially decreased verbal skills contribute to, as time passes, long-term academic difficulties, which secondarily decrease performance on the Verbal Scale (Vance et al., 1981). As stated by Tyszkowa (1990, p. 158), “...difficulties and failures in learning lasting for several years, resulting most frequently $[. .$.$] from delays or the disharmony of de-$ velopment. In the case of a lack of positive influences of the educational environment, they cause adverse changes in the dynamics of the development of a child. A student who was not provided with help at an appropriate time, facing difficulties, not keeping up with the progress made by their peers, experiencing constant situations of failure, withdraws from cognitive activity, restricts the scope of their interests, and that causes the deficit or the lack of mental training. The scope of such a student's knowledge and abilities is narrowed so much that he cannot participate in the intellectual activity of the entire class, while the family environment fails to provide this student with such stimuli. The consequence of that is the generally slowed down speed of development”.

\section{CONCLUSIONS}

The results of the present study suggest that the dynamics of change in the cognitive development of students having borderline intelligence ought to be observed carefully and analyzed by specialists working with those children. Due to the small number of participants in this study, generalization of the results is limited. Nevertheless, it seems clear that studies in this area should be broadened and continued. Information concerning changes occurring in time in the scope of cognitive functions of this group of students may be of critical importance for the reliability of the diagnosis and the process of therapy. It is important to assess appropriately the intellectual capacities of this group of students, not so much on the basis of general development, which may remain unchanged in the subsequent measurements, but rather specific cognitive skills, which may determine the actual capacities of an individual.

\section{References}

American Psychiatric Association (2013). Diagnostic and Statistical Manual of Mental Disorders ( $5^{\text {th }}$ ed.). Washington, DC: Authors.

Ahrens, J.A., Evans, R.G. \& Barnett, R. (1990). Factors related to dropping out of school in an incarcerated population. Educational \& Psychological Measurement, 50, 611-617.

Anderson, P.L., Cronin, M.E. \& Kazmierski, S. (1989). WISC-R stability and re-evaluation of learning-disabled students. Journal of Clinical Psychology, 45, 941-944.

Bauman, E. (1991). Stability of WISC-R scores in children with learning difficulties. Psychology in the Schools, 28, 95-100.

Cooter, K.S. \& Cooter, R.B. (2004). One size doesn't fit all: Slow learners in the reading classroom. The Reading Teacher, 57, 680-684.

Covin, T. (1977). Stability of the WISC-R for 9-yearolds with learning disabilities. Psychological Reports, 40, 1297-1298. 
Hassiotis, A., Strydom, A., Hall, I., Ali, A., Lawrence-Smith, G., Meltzer, H., Head, J. \& Bebbington, P. (2008). Psychiatric morbidity and social functioning among adults with borderline intelligence living in private households. Journal of Intellectual Disability Research, 52, 95-106.

Haynes, J.P., Howard, R.C. (1986). Stability of WISC-R scores in a juvenile forensic sample. Journal of Clinical Psychology, 42, 534-537.

Jankowska, A., Bogdanowicz, M. \& Łockiewicz, M. (2013). Dzieci szarej strefy - aktualizacja stanu wiedzy dotyczącej funkcjonowania psychospołecznego osób z inteligencją niższą niż przeciętna. Edukacja, 121, 24-36.

Jankowska, A., Bogdanowicz, M., Shaw, S.R. \& Łockiewicz, M. (2012). Zagrożenia społeczne osób z inteligencją niższą niż przeciętna - jak powstaje błędne koło społecznych niepowodzeń? In: K. Białobrzeska \& C. Kurkowski (ed.). Zagrożone człowieczeństwo. Część I. Zagrożenia w obszarze rodziny, dzieciństwa i okresu dorastania [Endangered humanity. Volume I. Risk factors within family, childhood, and adolescents] (pp. 223-239). Kraków: Oficyna Wydawnicza Impuls.

Kostrzewski, J. (1981). Osoby o niższym niż przeciętny poziomie sprawności intelektualnych. In: K. Kirejczyk (ed.). Upośledzenie umystowe [Mental retardation]. Warszawa: PWN.

Krasowicz-Kupis, G. \& Wiejak, K. (2006). Skala inteligencji Wechslera dla dzieci (WISC-R) w praktyce psychologicznej [Wechsler Intelligence Scale for Children (WISC-R) in practice]. Warszawa: Wydawnictwo Naukowe PWN.

MacMillan, D.L., Gresham, F.M., Bocian, K.M. \& Lambros, K. (1998). Current plight of borderline students: Where do they belong? Education \& Training in Mental Retardation \& Developmental Disabilities, 33, 83-94.

MacMillan, D.L., Gresham, F.M., Siperstein, G.N. \& Bocian, K.M. (1996). The labyrinth of IDEA: School decisions on referred students with subaverage general intelligence. American Journal on Mental Retardation, 101, 161-174.

Masi, G., Marcheschi, M. \& Pfanner, P. (1998). Adolescents with borderline intellectual functioning: Psychopathological risk. Adolescence, 33, 425-434.

Naglieri, J.A. \& Pfeiffer, S.I. (1983). Reliability and stability of the WISC-R for children with below average IQs. Educational and Psychological Research, 3, 203-208.

Nichols, E.G., Inglis, J., Lawson, J.S. \& MacKay, I. (1988). A cross-validation study of patterns of cognitive ability in children with learning difficulties, as described by factorially defined WISC-R Verbal and Performance IQs. Journal of Learning Disabilities, 21, 504-508.

Ryan, J.J., Sattler, J.M. \& Lopez, Sh.J. (2000). Age effects on Wechsler Adult Intelligence Scale-III sub- tests. Archives of Clinical Neuropsychology, 15, 311317.

Schmidt, H.P., Kuryliw, A.J., Saklofske, D.H. \& Yackulic, R.A. (1989). Stability of WISC-R scores for a sample of learning disabled children. Psychological Reports, 64, 195-201.

Shaw, S.R. (2008). An Educational Programming Framework for a Subset of Students With Diverse Learning Needs: Borderline Intellectual Functioning. Intervention in School and Clinic, 43, 291-299.

Smith, M.D. (1978). Stability of WISC-R subtest profiles for learning disabled children. Psychology in the Schools, 15, 4-7.

Spionek, H. (1970). Psychologiczna analiza trudności i niepowodzeń szkolnych [Psychological analysis of difficulties and school failure]. Warszawa: PWN.

Spionek, H. (1973). Zaburzenia rozwoju uczniów a niepowodzenia szkolne [Students' developmental difficulties and school failure]. Warszawa: PWN.

Stavrou, E. (1990). The long-term stability of WISC-R scores in mildly retarded and learning-disabled children. Psychology in the Schools, 27, 101-110.

Tyszkowa, M. (1990). Zdolności, osobowość i dziatalność uczniów [Skills, personality, and students' activity]. Warszawa: PWN.

Tuma, J.M. \& Applebaum, A.S. (1980). Reability and pratice effects on WISC-R IQ estimates in a normal population. Educational and Psychological Measurement, 40, 671-678.

Vance, H.B., Blixt, S., Ellis, R. \& Debell, S. (1981). Stability of the WISC-R for a sample of exceptional children. Journal of Clinical Psychology, 37, 397399.

Wechsler, D. (1974). Manual for the Wechsler Intelligence Scale for Children-Revised. New York: Psychological Corporation.

Wojnarska, A. (2003). Kompetencje szkolne uczniów z obniżoną sprawnością intelektualną. In: Z. Janiszewska-Nieścioruk (ed.). Człowiek z niepetnosprawnościq intelektualna [Person with intellectual disability]. (pp. 289-298). Kraków: Impuls.
Stability of WISC-R in borderline intelligence students 